\title{
Correlation between Cognitive Abilities and Social Functioning in Patients with Multiple Sclerosis
}

\author{
Krasimir Genov ${ }^{1}$, Maria Dimitrova ${ }^{2}$ \\ ${ }^{1}$ SMHAT, Sofia, Bulgaria \\ ${ }^{2}$ University Multiprofile Hospital for Active Treatment and Emergency Medicine, Sofia, Bulgaria
}

Corresponding author: Maria Dimitrova, NI Pirogov University Multiprofie Hospital for Active Treatment and Emergency Medicine, 21 Totleben Blvd., Sofia, Bulgaria; E-mail: dr.m.i.dimitrova@gmail.com; Tel.: +359 886850961

Received: 13 Sep 2020 Accepted: 13 Jan 2021 Published: 28 Feb 2022

Citation: Genov K, Dimitrova M. Correlation between cognitive abilities and social functioning in patients with multiple sclerosis. Folia Med (Plovdiv) 2022;64(1):33-40. doi: 10.3897/folmed.64.e58611.

\begin{abstract}
Introduction: Cognitive impairment has been found in all stages and subtypes of multiple sclerosis (MS). It has a broad negative impact on the lives of people with MS independent of physical symptoms. Perhaps the most severe and far-reaching effect is unemployment, which results in extensive personal, social, and financial costs. Cognition has been linked to unemployment in many countries and shown to mediate the effects of disability on employment status.

Aim: The primary aim of this study was to assess social functioning in the context of activities of daily living and employment in patients with MS and to find a correlation between them and cognitive performance in these patients. The secondary aim was to find an association between employment and factors such as demography, emotional factors, and disease progression.

Materials and methods: The research included a study group of 100 patients with MS meeting the defined exclusion and inclusion criteria, and a control group of 40 healthy subjects. Disability was assessed with the Expanded Disability Status Scale (EDSS). The employment status was appraised in interviews with the subjects. The patients were divided into two groups: employed (working on a full-time or part-time job) and unemployed (not-working). The study aimed to assess the cognitive performance of all subjects. We examined cognitive domains such as short-term memory, psychomotor speed, and executive functions with a battery of neuropsychological tests.
\end{abstract}

Results: We found a connection between performance on neuropsychological tests and employment and engagement in activities of daily living. Another main conclusion of our study is that unemployed are older patients with longer duration of disease. They have excessive fatigue and unsatisfied results and impairment of memory functions. As to the reasons we found in our study for losing a job, some identified factors are the presence of excessive fatigue (44\%), movement disorders (41\%), cognitive impairment (30\%), pain (15\%), dizziness (15\%), dexterity (11\%), emotional disorders, bowel and bladder disorders (7\%), visual deficit (7\%), and heat sensitivity (4\%).

Conclusions: Unemployed patients have severe depressive symptoms.

\section{Keywords}

cognitive functions, disability, EDSS, employment, social activities 


\section{INTRODUCTION}

Multiple sclerosis (MS) is an inflammatory condition affecting the central nervous system (CNS). It is the most common cause of acquired, non-traumatic disability in young adults. Alongside the physical disability associated with MS, significant non-motor manifestations are often present. Rates of depression and cognitive dysfunction are higher in patients with MS than in the general population. Cognitive dysfunction is particularly under-recognized, and at present limited opportunities for intervention or treatment are available. Studies have revealed that cognitive impairment is present in 40\%-65\% of individuals with clinically definite MS on neuropsychological testing. Cognitive impairment has been found in all stages of MS affecting all subtypes of MS., ${ }^{1,2}$ The condition has a broad negative impact on the lives of people with MS independent of physical symptoms. Perhaps the most severe and far-reaching effect is unemployment, which results in extensive personal, social, and financial costs. ${ }^{4,5}$ Cognition has been linked to unemployment in many countries. Cognition has been shown to mediate the effects of disability on employment status. ${ }^{3,6}$ Within 10 years of diagnosis, about $50 \%$ of people with MS get unemployed.

\section{AIM}

The primary aim of this study was to assess social functioning in the context of activities of daily living and employment of patients with MS and to find a link between them and cognitive performance in these patients. The secondary aim was to find an association between employment and factors such as demography, emotional factors, and disease progression.

\section{MATERIALS AND METHODS}

The present study included 100 patients with MS and a control group of 40 healthy subjects. All participants in the study signed an informed consent form. All patients in the study group met the revised McDonald diagnostic criteria for MS. The group was formed with the exclusion of patients with a history of neurological deficit before diagnosing MS (for example due to brain injury), growth impairment, abuses, and severe depression. The mean age of patients was $39.46 \pm 9.27$ years, disease duration - 7.91 \pm 5.53 , EDSS $-3.25 \pm 1.89$. The patients in the study group had different types of MS: primary progressive (4\%), secondary progressive (27\%), and relapsing-remitting type (69\%) (Fig. 2).

\section{Methods}

- Disability assessment with Expanded Disability Status Scale (EDSS).
- The employment status was appraised in interviews with the subjects and the patients were divided into two groups: employed (working on a full-time or part-time job) and unemployed (not-working).

- The study aimed to assess the cognitive performance in all subjects. We examined cognitive domains such as short-term memory, psychomotor speed, and executive functions using a battery of neuropsychological tests. The examination was first performed at the beginning of the study, at the same time of the day, between 9 and 11 a.m. The neuropsychological battery included the following neuropsychological tests:

\section{Paced auditory serial addition test (PASAT)}

This is a neuropsychological test used to assess capacity and rate of information processing and sustained and divided attention; in our study we used PASAT 2 seconds and PASAT 3 seconds.

PASAT is a measure of cognitive function that assesses auditory information processing speed and flexibility, as well as calculation ability. It was developed by Gronwell in 1977 and later adapted by Rao and colleagues in 1989 for use in MS. The test is conducted using audio cassette tape or compact disk to ensure standardization in the rate of stimulus presentation. Single digits are presented every 3 seconds and the patient must add each new digit to the one immediately prior to it. Shorter inter-stimulus intervals, e.g., 2 seconds or less have also been used with PASAT but tend to increase the difficulty of the task. Two alternate forms have been developed to minimize possible familiarity with the stimulus items when the PASAT is repeated over more than one occasion.

\section{Digit span forward (DSF)}

The Digit Span test is a subtest of both the Wechsler Adult Intelligence Scale (WAIS) and the Wechsler Memory Scales (WMS). Subjects are read a sequence of numbers and asked to repeat the same sequence back to the examiner in order (forward span) or in reverse order (backward span). Forward span captures attention efficiency and capacity. Backward span is an executive task particularly dependent on working memory. The Digit Span subtest can be scored as one summary value (this is the score which is age-normed and contributes to summary scores in the Wechsler tests), or separately for forwards and backwards performance. Forwards and backwards performance can be reported either as subscores (the number of correct items of each type) or as span scores (the maximum number of digits correctly produced forward or backward by the subjects).

\section{Verbal fluency test (VFT)}

Verbal fluency tests are a kind of psychological tests in which participants have to produce as many words as possible from a category in a given time (usually 60 seconds). This category can be semantic, including objects such as animals or fruits, or phonemic, including words beginning with a specified letter, such as $p$, for example. We used the 
semantic variant of the test and performed the test using three categories - animals, fruits, and vegetables.

\section{Visual analogue fatigue scale (VAFS)}

The scale consists of 18 items relating to the subjective experience of fatigue. Each item asks respondents to place an "X," representing how they currently feel, along a visual analog line that extends between two extremes (e.g., from "not at all tired" to "extremely tired").

\section{Symbol digit modalities scale (SDMT)}

This scale is used to assess the psychomotor speed. The SDMT is brief, easy to administer, and has demonstrated remarkable sensitivity in detecting not only the presence of brain damage but also changes in cognitive functioning over time and in response to treatment.

The SDMT involves a simple substitution task that normal children and adults can perform easily. Using a reference key, the test taker has 90 seconds to pair specific numbers with given geometric figures. Responses can be written or given orally, and administration time is just five minutes for either response mode. The AutoScore Test Form simplifies scoring.

\section{Hamilton depression rating scale and Zung self- rating depression scale.}

The Hamilton depression rating scale (HAM-D) has proven useful for many years as a way of determining a patient's level of depression before, during, and after treatment. It should be administered by a clinician experienced in working with psychiatric patients. Although the HAM-D form lists 21 items, the scoring is based on the first 17. It generally takes 15-20 minutes to complete the interview and score the results. Eight items are scored on a 5-point scale, ranging from 0 (not present) to 4 (severe). Nine items are scored from 0 to 2 .

The Zung self-rating depression scale is a 20 -item self-report questionnaire that is widely used as a screening tool, covering effective, psychological, and somatic symptoms associated with depression. The questionnaire takes about 10 minutes to complete, and items are framed in terms of positive and negative statements. It can be effectively used in a variety of settings, including primary care, psychiatric, drug trials, and various research situations. Each item is scored on a Likert scale ranging from 1 to 4 . A total score is derived by summing the individual item scores and ranges from 20 to 80 . Most people with depression score between 50 and 69 , while a score of 70 and above indicates severe depression.

\section{Statistical analysis}

Statistical analysis was performed using the Student's t-test at statistical significance of $p<0.05$. Spearman's rank correlation coefficient assesses how well the relationship between two variables can be described using a monotonic function. The Spearman correlation between two variables is equal to the Pearson correlation between the rank values of those two variables; while Pearson's correlation assesses linear relationships, Spearman's correlation assesses monotonic relationships (whether linear or not). If there are no repeated data values, a perfect Spearman correlation of +1 or -1 occurs when each of the variables is a perfect monotone function of the other. The Kolmogorov-Smirnov test (K-S test or KS test) is a nonparametric test of the equality of continuous, onedimensional probability distributions that can be used to compare a sample with a reference probability distribution (one-sample K-S test), or to compare two samples (two-sample K-S test). The Monte Carlo methods, or Monte Carlo experiments, are a broad class of computational algorithms that rely on repeated random sampling to obtain numerical results. The underlying concept is to use randomness to solve problems that might be deterministic in principle. They are often used in physical and mathematical problems and are most useful when other approaches are difficult or impossible to use.

\section{RESULTS}

We divided the patients into two subgroups: employed and unemployed based on data for their employment status from the interview. Then we compared the results of the cognitive test between both subgroups.

The results of the Student's t-test suggested that there was no statistically significant difference between the mean values of PASAT 2 seconds and PASAT 3 seconds in both groups - employed and unemployed $(p=0.290$ and $p=0.509$, respectively) (Fig. 1). Also, the results of the Kolmogorov-Smirnov test showed that there was no significant difference between employed and unemployed in cognitive performance on DSF and VAFS $(p=0.564$ and $p=0.295$, respectively) (Fig. 1). A detailed statistical analysis was performed trying to identify if the disease duration affects cognitive tasks' performance. Analysis of the quantitative variables in patients with multiple sclerosis showed that there was no statistically significant linear correlation between the disease duration and the results of the variables (results of PASAT, DSF, and VAFS, respectively) (Fig. 3).

Table 1 presents another important assessment, the searching of correlations between education and cognitive performance on PASAT 2 and 3 seconds, DSF, and VAFS. The analysis finds a mild negative but statistically significant linear correlation between education and short term verbal memory examined with DSF (correlational ratio $r=-0.174$ ). A similar analysis of correlations between age and the above mentioned quantitative variable shows no statistically significant linear correlations. Besides, there was a correlation between employment and disease progression $(p<0.0001)$ assessed with the Fisher criterion.

The Student's t-test was used to correlate the quantitative variables and employment in patients with multiple sclerosis. A statistically significant difference between the mean 
K. Genov et al

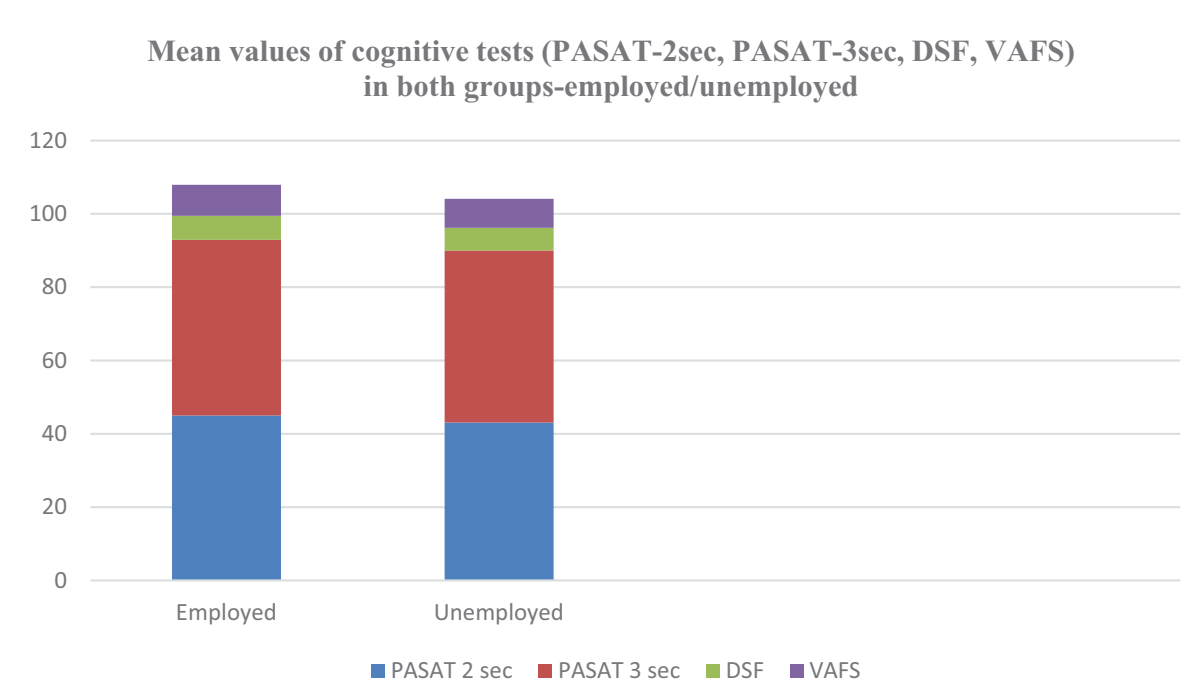

Figure 1. Mean values of PASAT 2sec, PASAT 3sec, DSF, VAFS in employed and unemployed subjects in control group.

Mean values of education, age, EDSS, VAFS in both groups employed/unemployed

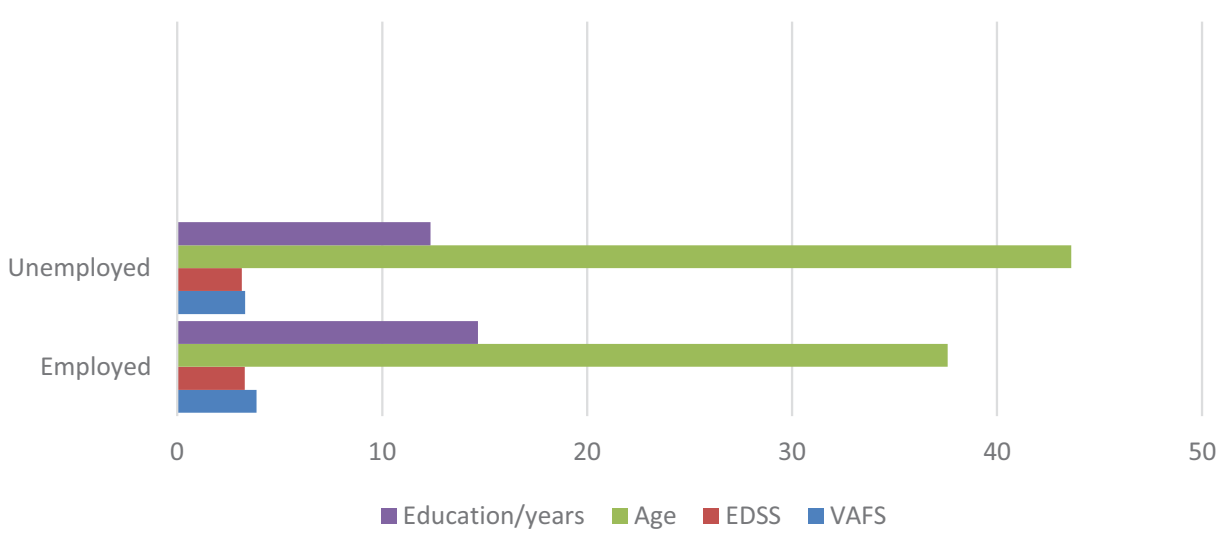

Figure 2. Mean values years of education, age, EDSS, VAFS/employed and unemployed patients with MS.

Mean values of SDMT in disease severity groups

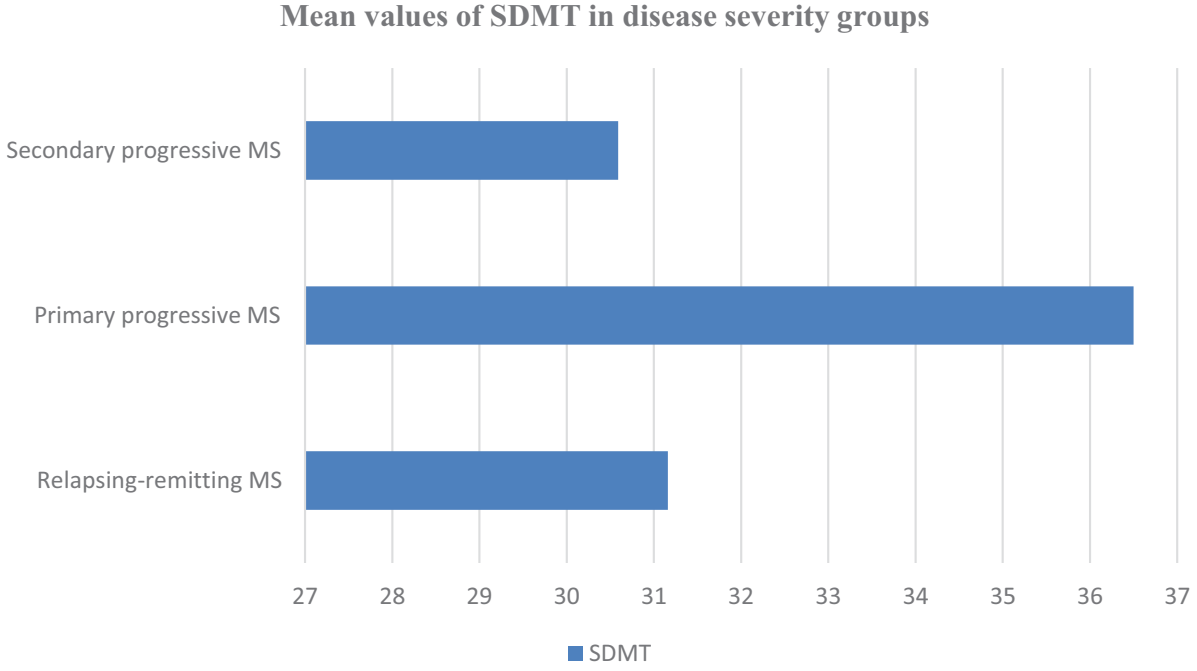

Figure 3. Mean values SDMT /disease progression. 
Table 1. Correlations between neuropsychological tests and education in patients with MS

\begin{tabular}{|c|c|c|c|c|c|c|c|}
\hline \multicolumn{8}{|c|}{ Correlations } \\
\hline & & & $\begin{array}{l}\text { Education } \\
\text { (yrs) }\end{array}$ & $\begin{array}{l}\text { PASAT } 2 \\
\text { sec. }\end{array}$ & $\begin{array}{l}\text { PASAT } 3 \\
\text { sec. }\end{array}$ & DSF & VAFS \\
\hline \multirow{10}{*}{ Spearman's rho } & \multirow{2}{*}{$\begin{array}{l}\text { Education } \\
\text { (yrs) }\end{array}$} & Correlation coefficient & 1.000 & 0.075 & 0.048 & $-0.174^{\star}$ & -0.097 \\
\hline & & Sig. (2-tailed) & & 0.379 & 0.574 & 0.040 & 0.254 \\
\hline & \multirow{2}{*}{$\begin{array}{l}\text { PASAT - } \\
2 \mathrm{sec}\end{array}$} & Correlation coefficient & 0.075 & 1.000 & $0.961 * *$ & $0.202^{*}$ & $0.274^{* *}$ \\
\hline & & Sig. (2-tailed) & 0.379 & & 0.000 & 0.016 & 0.001 \\
\hline & \multirow{2}{*}{$\begin{array}{l}\text { PASAT - } \\
3 \mathrm{sec}\end{array}$} & Correlation coefficient & 0.048 & $0.961^{* *}$ & 1.000 & $0.204^{\star *}$ & $0.283^{* *}$ \\
\hline & & Sig. (2-tailed) & 0.574 & 0.000 & & 0.016 & 0.001 \\
\hline & \multirow{2}{*}{ DSF } & Correlation coefficient & $-0.174^{\star *}$ & $0.202^{*}$ & $0.204^{*}$ & 1.000 & $0.407^{* *}$ \\
\hline & & Sig. (2-tailed) & 0.040 & 0.016 & 0.016 & & 0.000 \\
\hline & \multirow{2}{*}{ VAFS } & Correlation coefficient & -0.097 & $0.274^{\star *}$ & $0.283^{\star *}$ & $0.407^{\star *}$ & 1.000 \\
\hline & & Sig. (2-tailed) & 0.254 & 0.001 & 0.001 & 0.000 & \\
\hline
\end{tabular}

${ }^{\star}$ Weak association; ${ }^{*}$ Strong association

value of age in both groups (employed and unemployed) was found.

As can be seen in Table 2, there is no significant difference between employed and unemployed in EDSS $(p=0.320)$ and VAFS $(p=0.056)$, but the only difference is in the years of education (assessed by Kolmogorov-Smirnov test).

Another statistical correlation between SDMT and employment was tested. The Kolmogorov-Smirnov test showed that there is no statistically significant differences between employed and unemployed $(p=0.258)$. The Student's t-test scores do not present the difference between mean SDMT result and gender ( $p=0.341$ in both). SDMT results do not differ statistically significantly when correlated with the type of MS (RRMS, PPMS, SPMS) as well as by using the Kruskal-Wallis test.

The assessment of age, EDSS score, and SDMT results do not show a significant correlation between the two quantitative variables.
Table 3 shows that employed and unemployed patients do not display statistically significant differences in Hamilton score $(p=0.554)$, but differ in the Zung SDS score $(p=0.001)$. We could conclude that unemployed patients with MS have more severe depressive symptoms.

Table 4 gives us information about the lack of statistically significant difference between employment status and VFT results for the assessed categories of animals, fruits, vegetables and mean $(p=0.128, p=0.163, p=0.111, p=0.198$, respectively).

\section{DISCUSSION}

It has been 140 years since Charcot described "a marked enfeeblement of the memory" with "conceptions [that] are formed slowly" in persons with multiple sclerosis. Slowed cognitive processing speed and episodic memory decline are the most common cognitive deficits in MS, with

Table 2. Correlations between VAFS, education, EDSS/ employed and unemployed patients with MS

\begin{tabular}{|c|c|c|c|c|c|}
\hline \multicolumn{6}{|c|}{ Test Statistics ${ }^{b}$} \\
\hline & & & Education/years & EDSS & VAFS \\
\hline \multirow{3}{*}{ Most Extreme Differences } & Absolute & & 0.347 & 0.172 & 0.237 \\
\hline & Positive & & 0.000 & 0.117 & 0.118 \\
\hline & Negative & & -0.347 & -0.172 & -0.237 \\
\hline Kolmogorov-Smirnov Z & & & 1.607 & 0.795 & 1.098 \\
\hline Asymp. Sig. (2-tailed) & & & 0.011 & 0.553 & 0.179 \\
\hline \multirow{3}{*}{ Monte Carlo Sig. (2-tailed) } & Sig. & & $0.003^{\mathrm{a}}$ & $0.320^{\mathrm{a}}$ & $0.056^{\mathrm{a}}$ \\
\hline & \multirow{2}{*}{ 99\% Confidence Interval } & Lower Bound & 0.001 & 0.308 & 0.050 \\
\hline & & Upper Bound & 0.004 & 0.332 & 0.062 \\
\hline
\end{tabular}

a Based on 10000 sampled tables with starting seed 334431365.

${ }^{\mathrm{b}}$ Grouping variable: employment 
Table 3. Correlations between Hamilton and Zung score/employment in patients with MS

\begin{tabular}{|c|c|c|c|c|}
\hline \multicolumn{5}{|c|}{ Test Statistics $^{\text {b }}$} \\
\hline & & & Hamilton & Zung SDS-i \\
\hline \multirow{3}{*}{ Most extreme differences } & Absolute & & 0.092 & 0.326 \\
\hline & Positive & & 0.000 & 0.326 \\
\hline & Negative & & -0.092 & -0.011 \\
\hline Kolmogorov-Smirnov Z & & & 0.511 & 1.822 \\
\hline Asymp. Sig. (2-tailed) & & & 0.956 & 0.003 \\
\hline \multirow{3}{*}{ Monte Carlo Sig. (2-tailed) } & Sig. & & $0.554^{\mathrm{a}}$ & $0.001^{\mathrm{a}}$ \\
\hline & \multirow{2}{*}{ 99\% Confidence Interval } & Lower Bound & 0.541 & 0.000 \\
\hline & & Upper Bound & 0.567 & 0.002 \\
\hline
\end{tabular}

a Based on 10000 sampled tables with starting seed 334431365.

${ }^{\mathrm{b}}$ Grouping variable: employment

Table 4. Correlations between VFT/employment in patients with MS

\begin{tabular}{|c|c|c|c|c|c|c|}
\hline \multicolumn{7}{|c|}{ Test Statistics $^{\text {b }}$} \\
\hline & & & $\begin{array}{l}\text { VFT } \\
\text { animals }\end{array}$ & VFT fruits & $\begin{array}{l}\text { VFT veg- } \\
\text { etables }\end{array}$ & $\begin{array}{l}\text { VFT.X } \\
\text { mean }\end{array}$ \\
\hline \multirow{3}{*}{ Most Extreme Differences } & Absolute & & 0.166 & 0.159 & 0.176 & 0.155 \\
\hline & Positive & & 0.011 & 0.000 & 0.010 & 0.000 \\
\hline & Negative & & -0.166 & -0.159 & -0.176 & -0.155 \\
\hline Kolmogorov-Smirnov Z & & & 0,929 & 0.887 & 0.986 & 0.864 \\
\hline Asymp. Sig. (2-tailed) & & & 0.354 & 0.411 & 0.286 & 0.444 \\
\hline \multirow{3}{*}{ Monte Carlo Sig. (2-tailed) } & Sig. & & $0.128^{\mathrm{a}}$ & $0.163^{\mathrm{a}}$ & $0.111^{\mathrm{a}}$ & $0.198^{\mathrm{a}}$ \\
\hline & \multirow{2}{*}{ 99\% Confidence Interval } & Lower Bound & 0.119 & 0.154 & 0.103 & 0.188 \\
\hline & & Upper Bound & 0.137 & 0.173 & 0.119 & 0.209 \\
\hline
\end{tabular}

a Based on 10000 sampled tables with starting seed 334431365 .

${ }^{\mathrm{b}}$ Grouping variable: employment

additional difficulties in executive function, verbal fluency, and visuospatial analysis. ${ }^{7,8}$ Magnetic resonance imaging (MRI) has an essential role to play in the MS diagnosis and disease surveillance. The new MRI techniques allow us to gain a new understanding of the cognitive deficits in MS. Cognitive deficits are linked to a greater lesion load, the white matter lesion location, microstructural injury, gray matter lesions, cortical and subcortical gray matter brain atrophy, and discrepant patterns of cerebral activation with fMRI. Cognitive decline often emerges early in the disease. ${ }^{9}$ It is also known that the deficit is prevalent in patients with a progressive type of MS. The abovementioned allows us to form an understanding of our data. Cognitive deficit depends on the lesions' load and location, in both groups (employed and unemployed) there are patients with cognitive impairment and it is expected not to find a significant difference between the groups. ${ }^{10,11}$ The comorbid occurrence of psychiatric conditions in patients with MS may be due to several factors, including response to chronic illness, a relationship between immune function and depression and anxiety, disease process-related injury to the CNS, and possibly side effects of certain treatments. Psychiatric comorbidity can decrease adherence to disease-modifying therapy, increase fatigue, and decrease overall quality of life. ${ }^{12}$ A major depressive disorder is characterized by a combination of symptoms including feeling sad most of the day/most days, losing pleasure or interest in one's usual activities, sleeping problems, fatigue, psychomotor retardation or agitation, reduced appetite with weight loss or the converse, a negative self-image, feelings of guilt and self-blame, reduced concentration, and suicidal thinking. ${ }^{13,14}$ Fatigue, lack of concentration, altered sleep patterns, and memory issues are symptoms shared between depression and MS. The connection between MS and depression is two sided. On the one hand, patients with MS could have depression due to accepting the fact that they have a chronic disease and need a life-long therapy. This could affect their working ability. On the other hand, losing their job could be the reason for developing depressive symptoms. According to the data from the interview in our study, depressive symptoms are associated with losing jobs due to disease symptoms. ${ }^{15}$ 
Working is a part of the activities of daily living and integration in society. Recent studies on this topic report that patients with MS are more likely to be unemployed than those without MS. Some of our patients have a mild neurological deficit for a long time, but in some cases the disease progression is faster. The main result from our study is the presence of correlation between cognitive impairment in patients with MS and activities of daily living, social integration, and employment. It is extremely important to find at-risk patients and propose early therapy with cognitive rehabilitation and other alternative methods. ${ }^{16}$

Employment depends on some factors: years of education, fatigue, memory functions. The patients with higher education are more likely to be employed on a full-time or part-time basis. ${ }^{17,18}$ We found a connection between performance in the neuropsychological tests and employment and engagement in activities of daily living. Another main conclusion of our study is that unemployed patients tend to be older and with longer duration of the disease. They have excessive fatigue and unsatisfied results and impairment of memory functions.

Employment is essential for social functioning in MS patients. The advantages for patients who are employed: they are more self-confident and flexible in daily living, participate in intellectual activities, take more personal responsibilities, their self-esteem is at a good level, they are susceptible to news and ups and downs. ${ }^{19-21}$

Also, some patients define their job as "therapeutical". One of the patients in the study admitted in the interview: "I want to keep my job as long as possible, to be respected and important for somebody. No matter the efforts, it is worth. The truth is, I am part of the society due to my job". ${ }^{22,23}$ On the other hand, $40 \%$ of the unemployed patients with MS confess in the interview that they yearn to go back to work. ${ }^{24,25}$

In our study, we found the following reasons for losing a job: presence of excessive fatigue (44\%), movement disorders $(41 \%)$, cognitive impairment (30\%), pain (15\%), dizziness (15\%), loss of dexterity (11\%), emotional disorders, bowel and bladder disorders (7\%), visual deficit (7\%), and heat sensitivity (4\%).

\section{CONCLUSIONS}

We compared cognitive performance in patients with different types of MS with the employment status of these subjects and found out some important correlations:

- Patients who lost their jobs have unsatisfactory results on memory tasks.

- Disease progression and EDSS do not present any statistically significant difference between employed and unemployed.

- The results of the cognitive tests do not differ in both groups (employed and unemployed).

- Symptoms of depression are more frequent in unemployed patients.

\section{REFERENCES}

1. Andreasen AK, Jakobsen J, Soerensen L, et al. Regional brain atrophy in primary fatigued patients with multiple sclerosis. Neuroimage 2010; 50(2):608-15.

2. Bagnato F, Salman Z, Kane R, et al. T1 cortical hypointensities and their association with cognitive disability in multiple sclerosis. Mult Scler J 2010; 16(10):1203-12.

3. Benedict RH, Zivadinov R. Risk factors for and management of cognitive dysfunction in multiple sclerosis. Nat Rev Neurol 2011; 7(6):332-42.

4. Borghi M, Cavallo M, Carletto S, et al. Presence and significant determinants of cognitive impairment in a large sample of patients with multiple sclerosis. PloS One 2013; 8(7):e69820.

5. Cruz-Gomez J, Belenguer-Benavides A, Gonzalez-Rosa JJ, et al. A critical analysis of neuroimaging studies in relation to cognitive performance in multiple sclerosis patients. Revista de neurologia 2011; 53(6):337-50.

6. Fisk JD, Pontefract A, Ritvo PG, et al. The impact of fatigue on patients with multiple sclerosis. Can J Neurol Sci 1994; 21(1):9-14.

7. Marie RM, Defer GL. Memory and executive functions in multiple sclerosis: preliminary findings with a cognitive battery. Rev Neurol 2001; 157(4):402-8.

8. Zivadinov R, Sepcić J. Cognitive impairment in multiple sclerosis patients. Lijecnicki vjesnik 2004; 126(7):204-10.

9. Lincoln NB, Dent A, Harding J, et al. Evaluation of cognitive assessment and cognitive intervention for people with multiple sclerosis. J Neurol Neurosurg Psychiatry 2002; 72(1):93-8.

10. Foong J, Rozewicz L, Quaghebeur G, et al. Executive function in multiple sclerosis. The role of frontal lobe pathology. Brain 1997; 120(1):15-26.

11. Hoffmann S, Tittgemeyer M, von Cramon DY. Cognitive impairment in multiple sclerosis. Curr Opin Neurology 2007; 20(3):275-80.

12. Ghaffar O, Feinstein A. The neuropsychiatry of multiple sclerosis: a review of recent developments. Curr Opin Psychiatry 2007; 20(3):278-85.

13. Jehna M, Langkammer C, Wallner-Blazek M, et al. Cognitively preserved MS patients demonstrate functional differences in processing neutral and emotional faces. Brain Imaging Behav 2011; 5(4):241-51.

14. Krause M, Wendt J, Dressel A, et al. Prefrontal function associated with impaired emotion recognition in patients with multiple sclerosis. Behav Brain Res 2009; 205(1):280-5.

15. Sumowski JF, Benedict R, Enzinger C, et al. Cognition in multiple sclerosis: State of the field and priorities for the future. Neurology 2018; 90(6):278-88.

16. Mitchell AJ, Benito-León J, González JM, et al. Quality of life and its assessment in multiple sclerosis: integrating physical and psychological components of wellbeing. The Lancet Neurology 2005; 4(9):556-66.

17. Modestowicz R, Sosnowski P, Wender M, et al. Morphology of demyelination plaques vs. cognitive and emotional disorders in multiple sclerosis patients. Neurologia i neurochirurgia polska 2000; 34(1):23-34.

18. Ziemssen T. Multiple sclerosis beyond EDSS: depression and fatigue. J Neurol Sci 2009; 277:S37-41.

19. Krupp LB, Elkins LE. Fatigue and declines in cognitive functioning in multiple sclerosis. Neurology 2000; 55(7):934-9.

20. Maor Y, Olmer L, Mozes B. The relation between objective and subjective impairment in cognitive function among multiple sclerosis patients - the role of depression. Mult Scler J 2001; 7(2):131-5. 
21. Mendoza RJ, Pittenger DJ, Weinstein CS. Unit management of depression of patients with multiple sclerosis using cognitive remediation strategies: a preliminary study. Neurorehabil Neural Repair 2001; 15(1):9-14.

22. Genov K. Multiple sclerosis. 2002: 9-127.

23. Genov K. Changes in the cognitive function of multiple sclerosis pa- tients (clinical-psychological study). [Dissertation]. Sofia, 2003.

24. Genov K. Lifestyle and psychological problems in patients with multiple sclerosis. Sofia: XK; 2015.

25. Genov K. Factors influencing cognitive impairment in patients with multiple sclerosis (clinical-psychological study). [PhD thesis]. Sofia, 2015.

\title{
Корреляция между когнитивными способностями и социальным фрункционированием у пациентов с рассеянным склерозом
}

\author{
Красимир Генов ${ }^{1}$, Мария Димитрова ${ }^{2}$ \\ ${ }^{1}$ Вторая МБАЛ - София, София, Болгария \\ ${ }^{2}$ уМБАЛСМ „Н. И. Пирогов“, София, Болгария
}

Адрес для корреспонденции: Мария Димитрова, УМБАЛСМ „Н. И. Пирогов“, София, Болгария, бул. „Тотлебен“ № 21, София, Болгария; Е-mail: dr.m.i.dimitrova@gmail.com; Тел.: +359 886850961

Дата получения: 13 сентября 2020 Дата приемки: 13 января 2021 Дата публикации: 28 февраля 2022

Образец цитирования: Genov K, Dimitrova M. Correlation between cognitive abilities and social functioning in patients with multiple sclerosis. Folia Med (Plovdiv) 2022;64(1):33-40. doi: 10.3897/folmed.64.e58611.

\section{Резюме}

Введение: Когнитивные нарушения обнаруживаются на всех стадиях и подтипах рассеянного склероза (РС). Это оказывает серьёзное негативное влияние на жизнь людей с РС, независимо от физических симптомов. Возможно, самым тяжёлым и серьёзным последствием является безработица, которая приводит к чрезмерным личным, социальным и финансовым потерям. Когнитивные способности связаны с безработицей во многих странах, и было показано, что последствия инвалидности влияют на статус занятости.

Цель: Основная цель этого исследования состояла в том, чтобы оценить социальное функционирование в контексте повседневной деятельности и занятости пациентов с РС и установить корреляцию между ними и когнитивными способностями этих пациентов. Вторая цель состояла в том, чтобы установить связь между занятостью и такими факторами, как демография, эмоциональные факторы и развитие заболеваний.

Материалы и методы: В исследование была включена группа из 100 больных РС, отвечающих критериям включения и исключения, и контрольная группа из 40 здоровых лиц. Инвалидность оценивалась по расширенной шкале оценки инвалидности (РШОИ). Занятость была установлена в ходе интервью с участниками. Пациенты были разделены на две группы: занятые (полный или неполный рабочий день) и безработные (незанятые). Исследование было направлено на оценку когнитивных способностей всех испытуемых. Мы исследовали такие когнитивные области, как кратковременная память, скорость психомоторики и исполнительная функция, с помощью ряда нейропсихологических исследований.

Результаты: Обнаружена связь между выполнением нейропсихологических тестов и занятостью и вовлечённостью в повседневную деятельность. Еще один важный вывод из нашего исследования состоит в том, что безработные - это пожилые пациенты с более длительной продолжительностью болезни. Они страдают от чрезмерной утомляемости и неудовлетворительных результатов, нарушения функции памяти. Относительно причин потери работы одними из выявленных факторов являются наличие чрезмерной утомляемости (44\%), двигательных нарушений (41\%), когнитивных нарушений (30\%), боли $(15 \%)$, головокружения (15\%), ловкости рук. (11\%), эмоциональные расстройства, дисфункция кишечника и мочевого пузыря (7\%), дефицит зрения (7\%), чувствительность к теплу (4\%).

Заключение: Безработные пациенты страдают тяжелой депрессивной симптоматикой.

\section{Ключевые слова}

когнитивные функции, инвалидность, РШОИ, занятость, социальная активность 